\title{
Glucokinase is not the pancreatic B-cell glucoreceptor
}

\author{
W.J. Malaisse and A.Sener \\ Laboratory of Experimental Medicine, Brussels Free University, Brussels, Belgium
}

\begin{abstract}
Summary. A series of recent experimental findings are reviewed to indicate that glucokinase does not represent the pancreatic B-cell glucoreceptor. (1) Whether in liver, pancreatic islet or insulin-producing tumoral cell homogenates, glucokinase fails to yield a higher reaction velocity with $\alpha$ - than $\beta$ D-glucose. (2) At a high glucose concentration $(40 \mathrm{mmol} / \mathrm{l})$, when the phosphorylation of glucose by glucokinase is indeed higher with $\beta$ - than $\alpha$-D-glucose, no preference for $\beta$-D-glucose is observed in intact islets, as judged from the utilization of D-[5- $\left.{ }^{3} \mathrm{H}\right]$ glucose, production of lactic acid, oxidation of D$\left[\mathrm{U}^{14} \mathrm{C}\right.$ ]glucose, net uptake of ${ }^{45} \mathrm{Ca}$ or release of insulin. (3) The glucose 6-phosphate content of intact islets is higher in the presence of $\beta$ - than $\alpha$-D-glucose. (4) At a low glucose concentration $(3.3 \mathrm{mmol} / 1)$, when the participation of glucokinase to hexose phosphorylation is minimal, $\alpha$-D-glucose is still better metabolized and stimulates both ${ }^{45} \mathrm{Ca}$ net uptake and insulin release more efficiently than $\beta$-D-glucose, despite the fact that
\end{abstract}

hexokinase yields a higher reaction velocity with $\beta$ - than $\alpha$-Dglucose. (5) In intact islets, $\beta$-D-glucose is used preferentially to $\alpha$-D-glucose in the pentose cycle pathway as judged from the oxidation of $\alpha$ - or $\beta$-D-[1- $\left.{ }^{14} \mathrm{C}\right] \mathrm{glucose}$ relative to that of $\alpha$ or $\beta$-D-[6- $\left.{ }^{14} \mathrm{C}\right] \mathrm{glucose}$. (6) In islets removed from fasted rats, the rate of glycolysis is more severely decreased than expected from the repression of glucokinase. (7) The metabolism of glucose in tumoral insulin-producing cells differs, in several respects, from that in normal pancreatic islets, although the pattern of hexokinase and glucokinase activities is similar in these two types of cells. All these observations point to the participation of regulatory sites distal to glucose phosphorylation in the control of glucose metabolism in islet cells.

Key words: Pancreatic islets, insulin-producing tumoral cells, glucose anomers, glucokinase, hexokinase.

glycolysis in pancreatic islets exposed to the $\alpha$-as distinct from $\beta$-anomer of these two hexoses [6,7]. We attributed such a metabolic difference to the anomeric specificity of phosphoglucose isomerase and phosphoglucomutase, as reviewed in detail elsewhere [8]. Recently, however, Matschinsky et al. proposed that the anomeric specificity of hexose metabolism in islet cells is attributable to a limited preference of glucokinase for the $\alpha$-anomer of either D-glucose or D-mannose $[9,10]$. The latter claim was considered in the framework of the concept that glucokinase would act as a glucoreceptor in the pancreatic B-cell $[11,12]$.

In the present report, we will review recent experimental findings which clearly indicate that glucokinase is not the enzyme responsible for the anomeric specificity of glucose metabolism in islet cells.

\section{Is glucokinase an $\alpha$-stereospecific enzyme?}

In considering the possible role of glucokinase in the anomeric specificity of glucose metabolism in pancreatic islets, the first point to be discussed is whether glucoglucose or D-mannose coincides with a higher rate of 

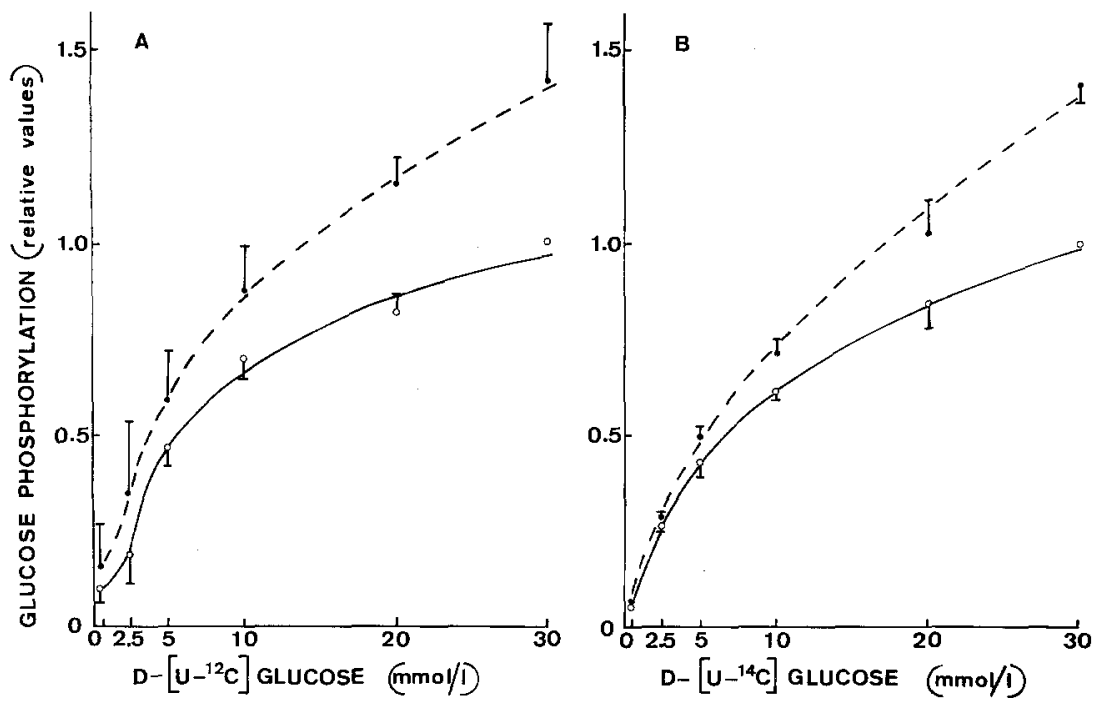

Fig. 1. Comparison of $\alpha$-D-glucose $(\mathrm{O}-\mathrm{O}$ ) and $\beta$-D-glucose (--) phosphorylation by liver homogenates at $7^{\circ} \mathrm{C}$. For the sake of comparison the results obtained by (A) a non-isotopic or (B) radioactive procedure are expressed relative to the mean value found within the same experiments in the presence of $\alpha$-D-glucose $(30 \mathrm{mmol} / \mathrm{l})$. Such a reference value averaged $6.48 \pm 1.34$ (left) and $4.67 \pm 0.52$ (right) $\mathrm{pmol} / 60 \mathrm{~min}$ per $\mu \mathrm{g}$ wet wt. $(n=4-6)$. Mean \pm SEM values are derived from three to six separate experiments

Table 1. Metabolic and functional variables in islet homogenates or intact islets incubated at $7^{\circ} \mathrm{C}$ in the absence or presence of $\alpha$ - or $\beta$-D-glucose $(40 \mathrm{mmol} / \mathrm{l})$

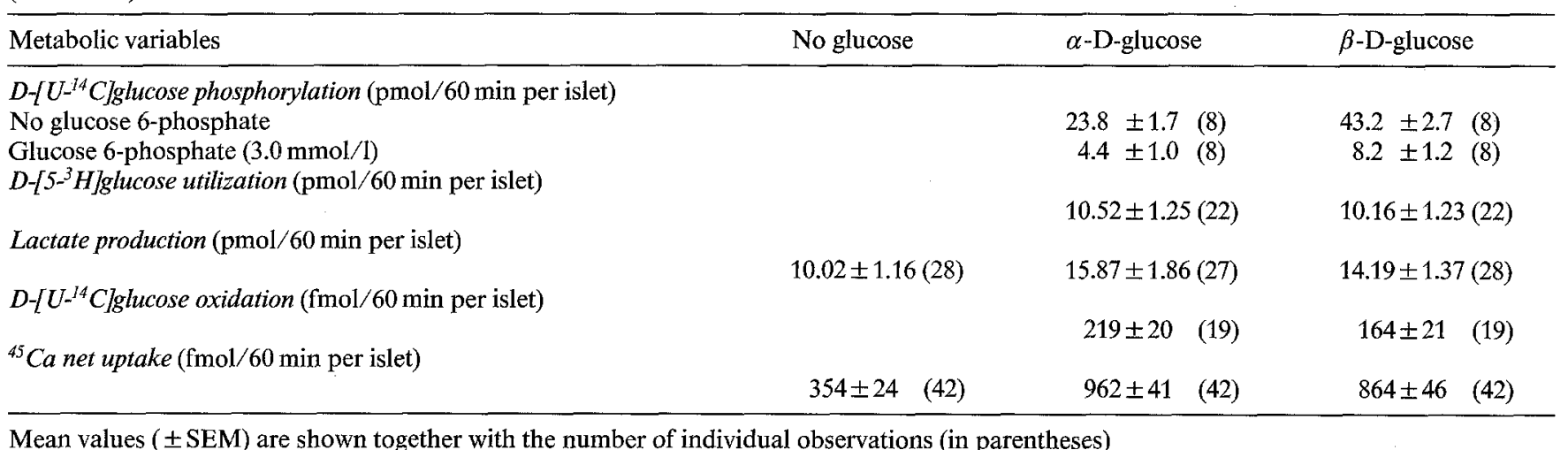

kinase is indeed an $\alpha$-stereospecific enzyme. Previous studies do not provide an unambiguous answer to this question. Salas et all. [13] first reported that, at a high concentration $(50 \mathrm{mmol} / \mathrm{l}), \alpha$ - and $\beta$-D-glucose are phosphorylated at the same rate by rabbit liver glucokinase. Miwa et al. [14], however, proposed that glucokinase displayed a higher affinity for $\alpha$ - than $\beta$-D-glucose, without any anomeric difference in maximal velocity. Meglasson and Matschinsky [9] reported that the maximal velocity is $15-20 \%$ lower, but the affinity is twice as high for $\alpha$ - than $\beta$-D-glucose. As a result of these two differences, the rate of glucose phosphorylation was somewhat higher with $\alpha$ - than $\beta$-D-glucose in a restricted range of concentration between 2 and $11 \mathrm{mmol} / 1$, with the opposite situation at higher glucose concentrations $(40-80 \mathrm{mmol} / \mathrm{l})$. Using both a nonradioisotopic and a radioisotopic procedure for the assay of glucokinase activity in rat liver homogenates, we observed that the apparend $\mathrm{K}_{\mathrm{m}}$ may be slightly lower for $\alpha$ - than $\beta$-D-glucose, but that the reaction velocity was always lower in the presence of the $\alpha$-rather than $\beta$-anomer, whatever the concentration of glucose (Fig.1). Comparable results were obtained when the glucokinase activity was examined in either pancreatic islet or insulin-producing tumoral cell homogenates [15].

Our findings with liver or islet cell glucokinase differ from those reported by Meglasson and Matschinsky [9] in one respect, namely the absence of a higher reaction velocity with $\alpha$-D-glucose at low concentrations of the hexose. Although the reason for these conflicting findings is not evident, we do not feel that glucokinase should be considered as an $\alpha$-stereospecific enzyme. Nevertheless, since the enzymatic data collected in different laboratories are conflicting, further experiments were designed to assess the possible role of glucokinase in the anomeric specificity of the metabolic and functional response in intact islet cells.

\section{Lack of $\beta$-stereospecificity of glucose metabolism in intact islets incubated at a high glucose concentration}

As already mentioned, at high glucose concentrations (e.g. $40 \mathrm{mmol} / 1$ ), the reaction catalyzed by glucokinase displays a higher velocity with $\beta$ - than $\alpha$-D-glucose, as 


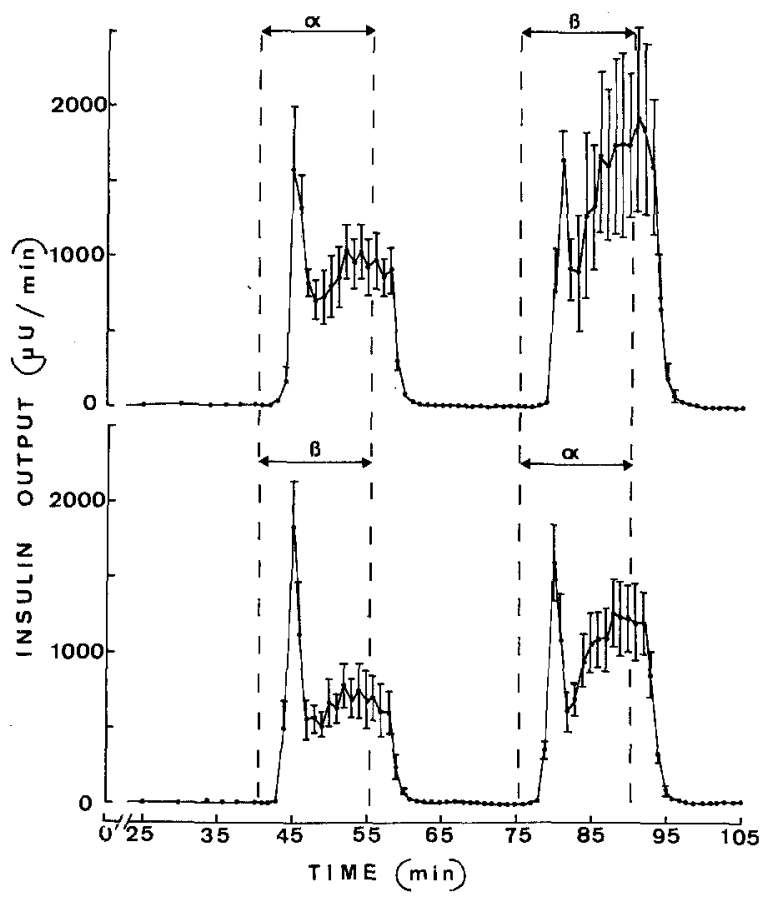

Fig. 2. Time course for insulin release from isolated perfused pancreases exposed for $15 \mathrm{~min}$ to either $\alpha$ - or $\beta$-D-glucose $(40 \mathrm{mmol} / 1)$ delivered from a side syringe maintained under ice. The dotted vertical lines indicate the period during which glucose was administered, no correction for dead space being introduced. Mean $\pm S E M$ values refer to three experiments in each case

judged from the data reported by Meglasson and Matschinsky [9] and Sener et al. [15]. Therefore, the rate of glycolysis in islets exposed to an elevated concentration of D-glucose would be higher with $\beta$ - than $\alpha$-D-glucose, if glucokinase were indeed to act as the key regulator of glucose metabolism in pancreatic islet cells. We therefore measured the phosphorylation of D-[U${ }^{14} \mathrm{Clglucose}$ in islet homogenates, as well as the metabolism of D-[5- $\left.{ }^{3} \mathrm{H}\right] \mathrm{glucose}$ and $\mathrm{D}-\left[\mathrm{U}-{ }^{14} \mathrm{C}\right] \mathrm{glucose}$, production of lactic acid, and net uptake of ${ }^{45} \mathrm{Ca}$ in intact islets exposed at $7{ }^{\circ} \mathrm{C}$ to $40 \mathrm{mmol} / 1 \alpha$ - or $\beta$-D-glucose [16].

The rate of glucose phosphorylation by islet homogenates incubated at $7^{\circ} \mathrm{C}$ in the presence of D-glucose $(40 \mathrm{mmol} / \mathrm{l})$ was higher $(p<0.001)$ in the case of $\beta$ - than $\alpha$-D-[U- $\left.{ }^{14} \mathrm{C}\right]$ glucose (Table 1). Even when glucose 6-phosphate was added to the reaction mixture in a high concentration (initial concentration of glucose 6-phosphate: $3.0 \mathrm{mmol} / \mathrm{l}$ ) in order to inhibit the low- $\mathrm{K}_{\mathrm{m}}$ hexokinase, the rate of phosphorylation of $\beta$-D-[U${ }^{14}$ Clglucose remained significantly higher than that of the corresponding $\alpha$-anomer $(p<0.05)$. However, in intact islets no significant anomeric differences were observed for the various metabolic and functional variables. The mean values for either D- $\left[5-{ }^{3} \mathrm{H}\right]$ glucose utilization, lactate production and D-[U- $\left.{ }^{14}\right]$ glucose oxidation tended, if anything, to be higher with $\alpha$ - than $\beta$-Dglucose. Such was also the case for the net uptake of ${ }^{45} \mathrm{Ca}$. When insulin release was measured at $37^{\circ} \mathrm{C}$ in isolated perfused pancreases, the secretory response to $\alpha$ -
D-glucose averaged $103.1 \pm 15.0 \%(n=6)$ of the paired response to $\beta$-D-glucose (Fig. 2). In the latter experiments, $\alpha$-D-glucose was given first in three cases, $\beta$-Dglucose being administered first in the three other cases. In all cases, the secretory rate was higher during the second than the first stimulation, with a paired ratio of $141.8 \pm 13.5 \%(p<0.05 ; n=6)$. This probably reflects, in part at least [17], a phenomenon of B-cell memory [18].

These results afford direct evidence against glucokinase being the B-cell stereospecific receptor. Thus, at the high glucose concentration $(40 \mathrm{mmol} / 1)$, the rate of phosphorylation by islet homogenates was higher with $\beta$-than $\alpha$-D-glucose. In the absence of glucose 6-phosphate, this situation could reflect, in part at least, the participation of hexokinase, which displays a higher maximal velocity with $\beta$ - than $\alpha$-D-glucose (see below). However, in the presence of glucose 6-phosphate, the residual rate of phosphorylation is mainly attributable to glucokinase and, nevertheless, remained higher with $\beta$ - than $\alpha$-D-glucose. The latter finding confirms that the rate of $\beta$-D-glucose phosphorylation, as catalyzed by glucokinase, exceeds that of $\alpha$-D-glucose, at least at a high concentration of hexose. Despite such an anomeric difference, the metabolic and functional response of intact islets failed to be higher in the presence of $\beta$ than $\alpha$-D-glucose. On the contrary, for all metabolic and functional variables, the trend was, if anything, in favour of the $\alpha$-anomer. The present work indicates therefore that, at high glucose concentration $(40 \mathrm{mmol} /$ 1), the rate of glycolysis in intact islets cells does not reflect the anomeric behaviour of glucokinase. This observation suggests, therefore, that regulatory sites distal to glucose phosphorylation participate in the metabolism of glucose anomers in islet cells.

\section{Anomeric specificity of hexokinase}

In homogenates of rat islets or insulin-producing tumoral cells, hexokinase accounts for a major fraction of the total rate of glucose phosphorylation measured in the absence of exogenous glucose 6-phosphate [19]. Although hexokinase is largely inhibited in intact islet cells [20], we investigated whether hexokinase could participate in the anomeric specificity of glucose metabolism in intact islets. For such a purpose, we characterized the anomeric behaviour of hexokinase in islets and other tissues. The results are summarized in Table 2 and indicate that in all mammalian tissues so far investigated (even in liver, [15]), the maximal velocity is significantly higher with $\beta$-than $\alpha$-D-glucose, but the $\mathrm{K}_{\mathrm{m}}$ value lower for $\alpha$-than $\beta$-D-glucose. This was also the case for the anomers of D-mannose, whether in pancreatic islet or parotid gland homogenates. Thus, in terms of both maximal velocity and affinity, anomeric behaviour of mammalian hexokinase represents a mirror image of that of yeast hexokinase [21-23]. This phylogenetic evolution is compatible with the view that anomeric speci- 
Table 2. Anomeric specificity of hexokinase

\begin{tabular}{|c|c|c|c|c|}
\hline Tissue & Hexose & $\begin{array}{l}\mathrm{V} \alpha / \mathrm{V} \beta \\
\text { (ratio) }\end{array}$ & $\mathbf{K}_{\mathrm{m}} \alpha$ & $\mathrm{K}_{\mathrm{m}} \beta$ \\
\hline Rat pancreatic islets & D-glucose & $0.702 \pm 0.027$ & $30.5 \pm 1.7$ & $78.5 \pm 4.5$ \\
\hline Insulin-producing tumoral cells & D-glucose & $0.690 \pm 0.021$ & $18.0 \pm 2.3$ & $33.0 \pm 2.1$ \\
\hline Rat parotid gland & D-glucose & $0.673 \pm 0.029$ & $16.7 \pm 2.2$ & $34.5 \pm 4.8$ \\
\hline Rat parotid gland & D-mannose & $0.626 \pm 0.054$ & $28.2 \pm 1.8$ & $55.6 \pm 2.5$ \\
\hline Breast cancer cells & D-glucose & $0.815 \pm 0.004$ & $35.7 \pm 3.1$ & $88.6 \pm 2.0$ \\
\hline
\end{tabular}

Mean values ( $\pm \mathrm{SEM}$ ) for the $\alpha / \beta$ ratio in maximal velocity $(\mathrm{V} \alpha / \mathrm{V} \beta)$ and the $\mathrm{K}_{\mathrm{m}}$ values for $\alpha$ - and $\beta$-D-glucose or mannose $\left(\mathrm{K}_{\mathrm{m}} \alpha, \mathrm{K}_{\mathrm{m}} \beta\right)$ are derived from measurements performed at $7^{\circ} \mathrm{C}$

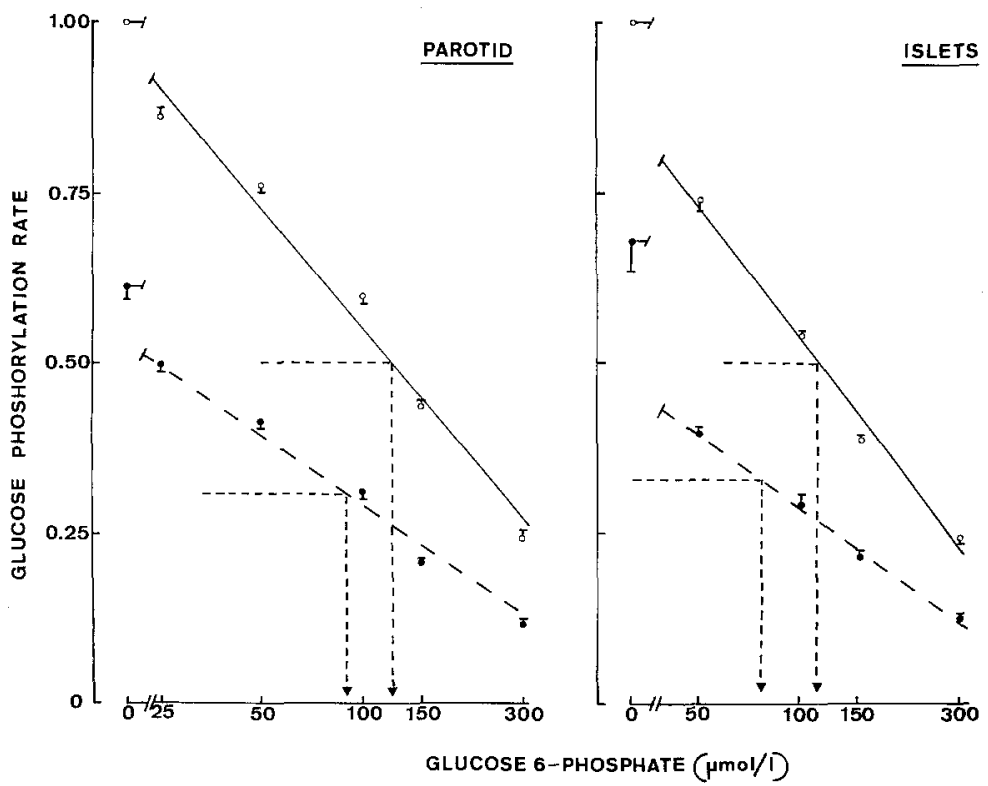

Fig.3. Effect of increasing concentrations of glucose 6-phosphate (logarithmic scale), in anomeric equilibrium, upon the phosphorylation of $\alpha$-D-[U-14 C]glucose (-- ) and $\beta$-D-[U-14 C]glucose $(\mathrm{O}-\mathrm{O})$ both used at an $0.5 \mathrm{mmol} / 1$ concentration, in parotid gland and pancreatic islet homogenates incubated at $7^{\circ} \mathrm{C}$. All results are expressed relative to the mean control value found within the same experiments in the presence of $\beta$-D-[U- $\left.{ }^{14} \mathrm{C}\right] \mathrm{glucose}$ and absence of glucose 6-phosphate. Such a reference value averaged $0.56 \pm 0.03 \mathrm{pmol} / \mathrm{min}$ per $\mu \mathrm{g}$ parotid (wet weight) and $0.74 \pm 0.04 \mathrm{pmol} / \mathrm{min}$ per islet. Mean $( \pm S E M)$ values refer to three to eight individual determinations. Also shown are the concentrations of glucose 6-phosphate yielding a $50 \%$ decrease in reaction velocity as judged from the regression lines ficity of enzymes reflects adaptation to a defined chemical environment, itself dictated by thermodynamic constraints $[8,24]$.

Since glucose 6-phosphate acts as a major inhibitor of hexokinase in pancreatic islets, we investigated also whether glucose 6-phosphate, in anomeric equilibrium, affects preferentially $\alpha$ - or $\beta$-D-[U- $\left.{ }^{14} \mathrm{C}\right]$ glucose phosphorylation in islet or parotid homogenates. The apparent $\mathrm{K}_{\mathrm{i}}$ for glucose 6-phosphate was lower in the presence of $\alpha$-than $\beta$-D-glucose (Fig.3). Thus, even in respect to inhibition by glucose 6-phosphate, the rate of glucose phosphorylation by hexokinase would be expected to be higher with $\beta$ - than $\alpha$-D-glucose.

At this point, it should be noted that, in two independent reports it was observed that the concentration of glucose 6-phosphate in intact islets was higher in the presence of $\beta$ - than $\alpha$-D-glucose when the hexose was used at concentrations in the range of 6.0-7.2 mmol [6, 25]. This finding, already reported 10 years ago, clearly argues against the view that the alleged $\alpha$-stereospecificity of glucokinase would represent the major determinant of the anomeric difference in the rate of glycolysis in intact islet cells. It may help to explain, however, that the anomeric preference of hexokinase for $\beta$-D-glucose is masked in intact cells [26] as a result of a higher glucose-6-phosphate content in cells exposed to $\beta$ - as distinct from $\alpha$-D-glucose.

\section{$\alpha$-Stereospecificity of metabolism in intact islets exposed to a low concentration of glucose}

The fact that hexokinase displays a higher maximal velocity with $\beta$-than $\alpha$-D-glucose led us to scrutinize the anomeric stereospecificity of glucose metabolism in intact islets exposed to a low concentration $(3.3 \mathrm{mmol} / \mathrm{l})$ of glucose anomers [27]. This low concentration was selected to prevent or, at least, minimize the contribution of glucokinase to the phosphorylation of glucose. The results of this study are summarized in Table 3.

In the islet homogenates, the rate of D-[U- $\left.{ }^{14} \mathrm{C}\right] \mathrm{glu}$ cose or D-[U-12 C]glucose phosphorylation was higher with $\beta$ - than $\alpha$-D-glucose. Even in the presence of a very high concentration of glucose 6-phosphate (initial 
Table 3. Metabolic and functional variables in islet homogenates or intact islets incubated at $7^{\circ} \mathrm{C}$ in the absence or presence of $\alpha$ - or $\beta$-D-glucose (3.3 mmol/1)

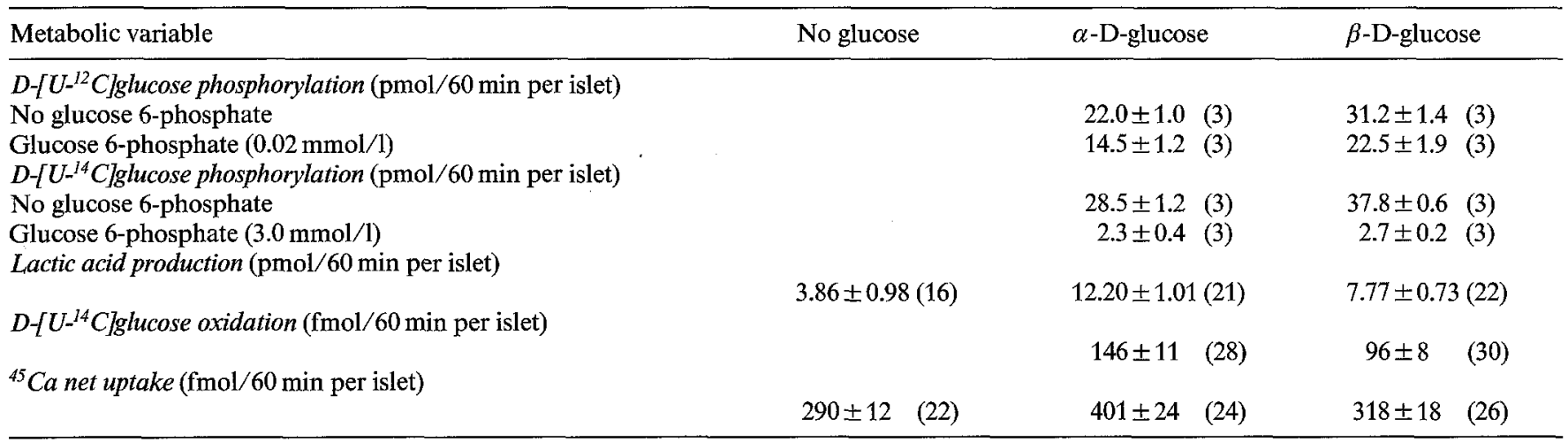

Mean values ( \pm SEM) are shown together with the number of individual observations (in parentheses)

Table 4. Metabolism of $\alpha$ - and $\beta$-D-glucose $(5.6 \mathrm{mmol} / \mathrm{l})$ in islets incubated at $7^{\circ} \mathrm{C}$

\begin{tabular}{|c|c|c|}
\hline Metabolic variables & $\alpha$-D-glucose & $\beta$-D-glucose \\
\hline $\begin{array}{l}D-\left[5-{ }^{3} \mathrm{H}\right] g l \text { gcose } \\
\text { utilization } \\
\text { (pmol/ } 60 \mathrm{~min} \text { per } \\
\text { islet) }\end{array}$ & $7.03 \pm 0.59(21)$ & $4.12 \pm 0.36(21)$ \\
\hline $\begin{array}{l}D-\left[1-{ }^{I 4} C\right] g l u c o s e \\
\text { oxidation } \\
\text { (fmol/ } 60 \mathrm{~min} \text { per } \\
\text { islet) }\end{array}$ & $289.7 \pm 22.9(21)$ & $350.9 \pm 21.9$ (19) \\
\hline $\begin{array}{l}D-\left(6-{ }^{I 4} \mathrm{C} / g \text { lucose }\right. \\
\text { oxidation } \\
\text { (fmol/ } 60 \mathrm{~min} \text { per } \\
\text { islet) }\end{array}$ & $94.3 \pm 12.3(29)$ & $47.9 \pm 6.3$ \\
\hline $\begin{array}{l}D-\left[1{ }^{14} C\right] g l u c o s e \\
D-\left[6{ }^{14} C\right] g l u c o s e \\
\text { oxidation } \\
\text { (ratio) }\end{array}$ & $3.07 \pm 0.47(21 / 29)$ & $7.32 \pm 1.07(19 / 29)$ \\
\hline
\end{tabular}

Mean values ( \pm SEM) are shown together with the number of individual observations (in parentheses)

concentration of glucose-6-phosphate: $3.0 \mathrm{mmol} / \mathrm{l}$ ), no inversion of the $\alpha$-stereospecific anomeric preference could be detected. Yet, in intact islets the rate of glycolysis was much higher with $\alpha$ - than $\beta$-D-glucose, as judged from either the glucose-induced increment in lactate production or oxidation of $\mathrm{D}-\left[\mathrm{U}-{ }^{14} \mathrm{C}\right]$-glucose. Likewise, the net uptake of ${ }^{45} \mathrm{Ca}$ was significantly higher in islets incubated at $7^{\circ} \mathrm{C}$ with $\alpha$ - than $\beta$-D-glucose, and this coincided with a higher secretory response in isolated perfused pancreas exposed at $37^{\circ} \mathrm{C}$ to the same low concentration $(3.3 \mathrm{mmol} / \mathrm{l})$ of $\alpha$ - as distinct from $\beta$-Dglucose (Fig. 3). Incidentally, in order to characterize the secretory response to this low concentration of glucose, the experiments were conducted in the presence of $\mathrm{L}$ leucine $(10 \mathrm{mmol} / \mathrm{l})$ administered throughout the perfusion. After correction for the mean control output found within each experiment just prior to and immediately after stimulation by D-glucose, the glucose-induced increment in insulin secretion was much higher $(p<0.001)$ in response to the $\alpha$-anomer $(+37.8 \pm$ $4.9 \mu \mathrm{U} / \mathrm{min}$ ) than in response to the $\beta$-anomer $(+14.1 \pm 2.2 \mu \mathrm{U} / \mathrm{min})$. Comparable results were obtained when the secretory response to the two anomers was tested in pancreases perfused in the absence of $\mathrm{Ca}^{2^{+}}$, but in the presence of both $\mathrm{Ba}^{2^{+}}(2 \mathrm{mmol} / \mathrm{l})$ and theophylline $(1.4 \mathrm{mmol} / \mathrm{l})$.

These findings clearly indicate that the metabolic, ionic and secretory responses of islet cells display $\alpha$-anomeric specificity even when glucose is used at a low concentration $(3.3 \mathrm{mmol} / \mathrm{l})$ selected to minimize the contribution of glucokinase to hexose phosphorylation. Thus, from prior observations $[19,28,29]$, it was calculated that the contribution of glucokinase to the overall rate of glucose phosphorylation by islet homogenates did not exceed $3.1-7.9 \%$ at the low glucose concentration $(3.3 \mathrm{mmol} / \mathrm{l})$.

The situation found in the islets exposed to a low concentration of $\alpha$ - or $\beta$-D-glucose is reminiscent of that recently characterized in rat erythrocytes [26]. Indeed, in erythrocytes the phosphorylation of D-glucose is catalyzed solely by a hexokinase which, like in other murine tissues, displays a higher maximal velocity with $\beta$ - than $\alpha$-D-glucose (Table 2). Yet, the glucose-induced increment in lactic acid output is higher in erythrocytes exposed to $\alpha$-than $\beta$-D-glucose [26]. Thus, the presence or participation of glucokinase is not a prerequisite for the $\alpha$-stereospecifity of glycolysis. Instead, data obtained in either islets exposed to a low glucose concentration or erythrocytes point to a key role for $\alpha$-stereospecific enzymes, such as phosphoglucose isomerase and phosphoglucomutase, in the anomeric specificity of glycolysis, as reviewed elsewhere [8].

\section{Preferential utilization of $\beta$-D-glucose 6-phosphate in the pentose cycle}

The observations so far reviewed all point to the existence of regulatory sites distal to glucose phosphorylation in the control of D-glucose metabolism in islet 


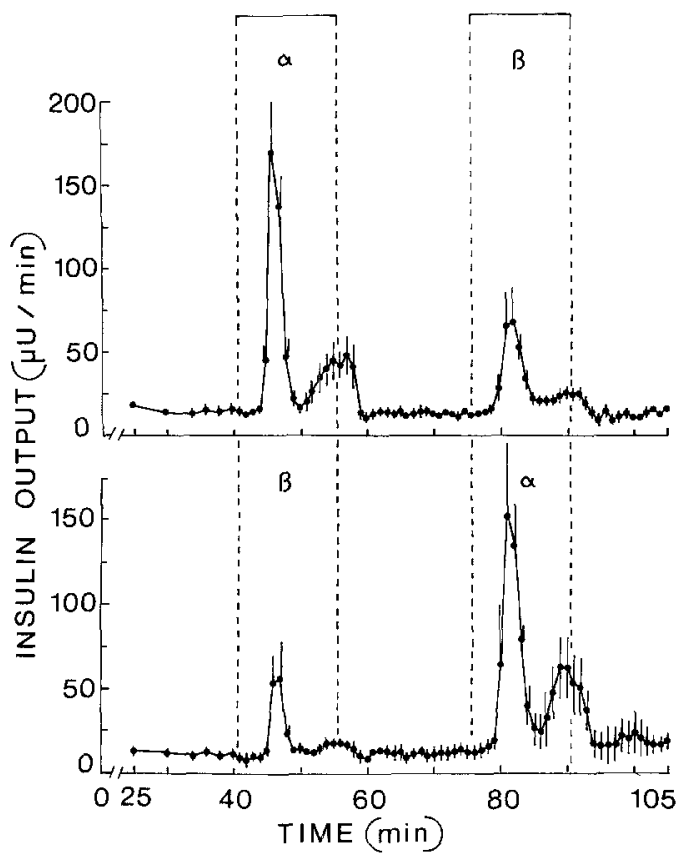

Fig.4. Insulin output from isolated perfused pancreases exposed throughout perfusion to L-leucine $(10 \mathrm{mmol} / \mathrm{l})$. During the period indicated by the vertical dotted lines, either $\alpha$ - or $\beta$-D-glucose $(3.3 \mathrm{mmol} / \mathrm{l})$ was administered from a side syringe maintained under ice, no correction being introduced for the dead space of the perfusion system. Mean $( \pm S E M)$ values refer to three experiments in each case

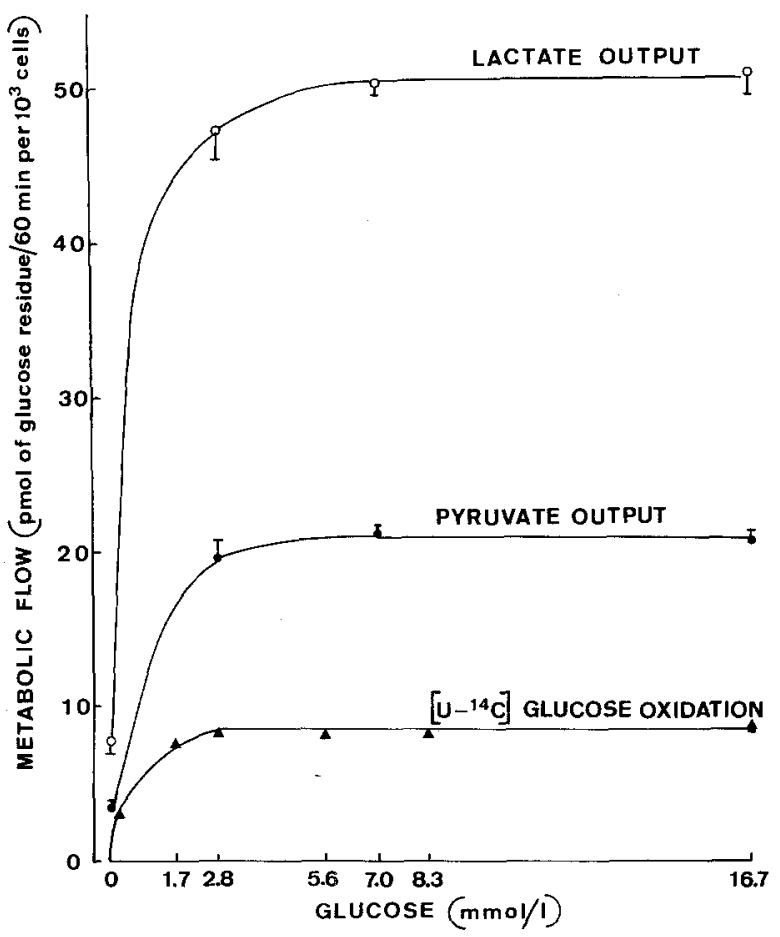

Fig.5. Output of lactic and pyruvic acids and oxidation of D-[U${ }^{14} \mathrm{C}$ glucose in RINm5F cells incubated at increasing concentrations of D-glucose. Mean values ( $\pm S E M$, whenever it exceeds the size of the mean symbol) refer to 28-44 (lactate output), 16-32 (pyruvate output) and 8-28 (glucose oxidation) individual measurements cells. For instance, we have documented previously the $\alpha$-stereospecificity of phosphoglucose isomerase in islet homogenates [6] and underlined its relevance to the anomeric difference in the rate of glycolysis [8]. At variance with phosphoglucose isomerase, the first enzyme in the pentose cycle, namely glucose-6-phosphate dehydrogenase, was shown to represent a $\beta$-stereospecific enzyme in islet homogenates [6]. If, as postulated by Matschinsky and his colleagues, glucokinase were to be responsible for the anomeric specificity of glucose metabolism in pancreatic islets and were to display preference for $\alpha$-D-glucose at close-to-physiological glucose concentrations, all metabolic fluxes beyond glucose 6-phosphate generation would be expected to be higher in islets exposed to $\alpha$-rather than $\beta$-D-glucose. These considerations led us to measure the flow rate through the pentose cycle in islets exposed at $7^{\circ} \mathrm{C}$ to the anomers of D-glucose at a concentration of $5.6 \mathrm{mmol} / \mathrm{l}$. In doing so, we took advantage of the isolation of purified $\alpha$ - and $\beta$-D-glucose labelled with ${ }^{14} \mathrm{C}$ in positions 1 and 6 , respectively.

The rate of $\beta$-D- $\left[1-{ }^{14} \mathrm{C}\right]$ glucose oxidation was slightly but not significantly higher than that of $\alpha$-D$\left[1-{ }^{14} \mathrm{C}\right]$ glucose oxidation $(p<0.07$; Table 4$)$. However, the $\alpha$-anomer of D-[6- $\left.{ }^{14} \mathrm{C}\right]$-glucose was oxidized at a higher rate than the corresponding $\beta$-anomer $(p<$ 0.005 ). The overall rate of glucose utilization, as judged from the production of ${ }^{3} \mathrm{H}_{2} \mathrm{O}$ by islets exposed to $\mathrm{D}$ $\left[5-{ }^{3} \mathrm{H}\right]$ glucose, was also higher in presence of the $\alpha$ - than $\beta$-anomer $(p<0.001)$. The oxidation of $\left[1-{ }^{14} \mathrm{C}\right] \mathrm{glucose}$ largely exceeded that of $\left[6-{ }^{14} \mathrm{C}\right] \mathrm{glucose}$, whether in the presence of $\alpha$ - or $\beta$-D-glucose. The ratio of $\mathrm{D}$ $\left[1-{ }^{14} \mathrm{C}\right]$ glucose/D-[6- $\left.{ }^{14} \mathrm{C}\right]$ glucose oxidation was much lower in the case of $\alpha$-than $\beta$-D-glucose $(p<0.001)$. Likewise, when the fraction of the total metabolism of glucose that occurs by the pentose cycle pathway was calculated according to Katz and Wood [30], the $\beta / \alpha$ ratio amounted to 2.73. Even when corrected for glucose utilization, the flow rate through the pentose pathway remained higher with $\beta$ - than $\alpha$-D-glucose with a $\beta / \alpha$ ratio close to 1.60 . Incidentally, at the same glucose concentration and at the same temperature, $\alpha$-D-glucose stimulated more than $\beta$-D-glucose the net uptake of ${ }^{45} \mathrm{Ca}(p<0.005)$, which averaged $727 \pm 45$ and $549 \pm$ $39 \mathrm{fmol} /$ islet at the 60 th $\mathrm{min}$ of incubation $(n=22$ in both cases).

These metabolic findings have several implications. First, they confirm that $\alpha$-D-glucose is metabolized more efficiently than $\beta$-D-glucose in islet cells exposed to a close-to-physiological concentration of the hexose. Second, since ${ }^{45} \mathrm{Ca}$ net uptake and insulin release are higher in islets exposed to $\alpha$-than $\beta$-D-glucose at these glucose concentrations [6], the present results suggest that the generation of NADPH in the pentose cycle pathway does not represent a major or, at least, the sole determinant of the functional response of islet cells to glucose. Third, our data provide the first demonstration that, in intact cells, $\beta$-D-glucose 6-phosphate is utilized 
preferentially to $\alpha$-D-glucose 6-phosphate in the pentose cycle, as expected from the anomeric specificity of glucose 6-phosphate dehydrogenase. Our data demonstrate, therefore, the existence of an anomerically specific regulatory site distal to glucose 6-phosphate generation. This implies that the rate of anomerization of glucose 6-phosphate is not sufficiently rapid to impede expression of the anomeric specificity of enzymes involved in the catabolism of this hexose phosphate. In other words, the present findings again illustrate that the metabolism of glucose anomers in islet cells is not regulated solely at the glucokinase level.

\section{Physiological and pathological dissociation between glucokinase activity and glycolysis in islet cells}

The evidence so far reviewed convincingly indicates that glucokinase is not the enzyme responsible for the $\alpha$-stereospecificity of glycolysis in islet cells. There are other arguments, however, to deny the alleged role of glucokinase as the B-cell glucoreceptor. Thus, there are at least two situations characterized by a dissociation between changes in glucokinase activity and glycolytic rate, respectively, in islet cells. The first situation refers to the influence of fasting upon islet function, whilst the second concerns the metabolism of glucose in tumoral insulin-producing cells.

In the first of these instances, it was shown that the rate of glycolysis in islets removed from fasted rats is much more severely impaired [31] than expected from the decrease in glucokinase activity [19, 32]. This situation coincided with a failure of glucose to increase the glucose 1,6-bisphosphate content of islets removed from fasted rats [31]. The data were interpreted, therefore, in support of the view that phosphofructokinase needs to be activated by suitable hexose bisphosphates, in order for the rate of phosphorylation of fructose 6-phosphate to keep pace with its generation rate [33]. In the same perspective, we have recently indicated that the glucose-induced changes in the content of fructose 2,6-bisphosphate in intact islets or purified B cells are sufficiently marked and sufficiently rapid to indeed participate in the control of phosphofructokinase activity in response to an increase in glucose concentration [34].

In the second instance, namely in insulin-producing tumoral cells, we were unable to detect any gross difference in the relative activities of hexokinase and glucokinase when compared with the situation found in normal islets cells [35]. This is in agreement with data obtained by Meglasson and Matschinsky [36], but at variance with those reported by Halban et al. [37]. Despite the similarity in the pattern of glucose phosphorylation found at increasing concentrations of glucose in tumoral cell and pancreatic islet homogenates, respectively, several anomalies of glucose metabolism were present in the RINm5F cells. For instance, the rate of glucose metabolism reached a close-to-maximal value at a glucose concentration of $2.8 \mathrm{mmol} / \mathrm{l}$ (Fig. 5). Moreover, the rate of glucose oxidation relative to that of glucose utilization was much lower in the tumoral cells than in normal pancreatic islets [38]. Lastly, the lactate/pyruvate ratio was lower in the tumoral cells than that measured in pancreatic islets, whether at low or high glucose concentration [31]. The latter two anomalies clearly indicate that the mitochondrial oxidation of pyruvate and its cytosolic conversion to lactate represent regulatory sites in glucose metabolism susceptible to perturbation in pathological situations, independently of any change in glucokinase activity.

\section{Conclusion}

The anomeric specificity of hexose utilization in pancreatic islets, and the perturbation of glucose catabolism in either islets removed from fasted rats or tumoral insulin-producing cells illustrate the relevance of regulatory steps distal to glucose phosphorylation in the control of glucose metabolism in islet cells. From these converging observations and when considering the original definition given to the B-cell glucoreceptor [3], we conclude that it represents not solely an unfair verbal pirouette but also, and more importantly, a misleading concept to equate glucokinase with such a receptor.

Acknowledgements. The original work presented in this review was supported by grants from the Belgian Foundation for Scientific Medical Research and Belgian Ministry of Scientific Policy. We are grateful to S.P. Dufrane, M.-H. Giroix, V. Leclercq-Meyer and F. Malaisse-Lagae for their collaboration to this work.

\section{References}

1. Malaisse WJ (1973) Insulin secretion: multifactorial regulation for a single process of release. Diabetologia 9:167-173

2. Matschinsky FM, Landgraf R, Ellerman J, Kotler-Brajtburg J (1972) Glucoreceptor mechanisms in islets of Langerhans. Diabetes 21 (Suppl 2): 555-569

3. Matschinsky FM, Ellerman J, Stillings S, Raybaud F, Pace C, Zawalich W (1975) Hexoses and insulin secretion. In: Hasselblatt A, Bruchhausen Fv (eds) Insulin, Part 2. Springer, Heidelberg, pp 79-114

4. Malaisse WJ, Sener A, Herchuelz A, Hutton JC (1979) Insulin release: the fuel hypothesis. Metabolism 28: 373-386

5. Malaisse WJ (1983) Insulin release: the fuel concept. Diab Metab 9:313-320

6. Malaisse WJ, Sener A, Koser M, Herchuelz A (1976) Simulus-secretion coupling of glucose-induced insulin release. XXIV. Metabolism of alpha and beta-D-glucose in isolated islets. J Biol Chem 251: 5936-5943

7. Sener A, Malaisse-Lagae F, Lebrun P, Herchuelz A, LeclercqMeyer V, Malaisse WJ (1982) Anomeric specificity of D-mannose metabolism in pancreatic islets. Biochem Biophys Res Commun 108: $1567-1573$

8. Malaisse WJ, Malaisse-Lagae F, Sener A (1983) Anomeric specificity of hexose metabolism in pancreatic islets. Physiol Rev 63: $773-786$ 
9. Meglasson MD, Matschinsky FM (1983) Discrimination of glucose anomers by glucokinase from liver and transplantable insulinoma. J Biol Chem 258: 6705-6708

10. Meglasson DM, Schinco M, Matschinsky FM (1983) Mannose phosphorylation by glucokinase from liver and transplantable insulinoma. Cooperativity and discrimination of anomers. Diabetes 32: $1146-1151$

11. Meglasson MD, Matschinsky FM (1984) New perspectives on pancreatic islet glucokinase. Am J Physiol 246: E1-E13

12. Garfinkel D, Garfinkel L, Meglasson MD, Matschinsky FM (1984) Computer modelling identifies glucokinase as glucose sensor of pancreatic B-cell. Am J Physiol 247: R527-R536

13. Salas J, Salas M, Vinuela E, Sols A (1965) Glucokinase of rabbit liver. Purification and properties. J Biol Chem 240: 1014-1018

14. Miwa I, Inagaki K, Okuda J (1983) Preference of glucokinase for the $\alpha$-anomer of hexose: relation to $\alpha$-anomer preference in hexose-induced insulin release by pancreatic islets. Biochem Int 7 : $449 \sim 454$

15. Sener A, Giroix M-H, Dufrane SP, Malaisse WJ (1985) Anomeric specificity of hexokinase and glucokinase activities in liver and insulin-producing cells. Biochem $\mathbf{J}$ (in press)

16. Sener A, Giroix M-H, Leclercq-Meyer V, Marchand J, Malaisse WJ (1985) Anomeric dissociation between glucokinase activity and glycolysis in pancreatic islets. Biochem Int 11: 77-84

17. Devis G, Van Obberghen E, Somers G, Malaisse-Lagae F, Orci L, Malaisse WJ (1974) Dynamics of insulin release and microtubular-microfilamentous system. II. Effect of vincristine. Diabetologia 10: $53-59$

18. Grill V, Cerasi E (1978) Immediate and time-dependent effects of glucose on insulin release from rat pancreatic tissue. Evidence for different mechanisms of action. J Clin Invest 61: 1034-1043

19. Malaisse WJ, Sener A, Levy J (1976) The stimulus-secretion coupling of glucose-induced insulin release. XXI. Fasting-induced adaptation of key glycolytic enzymes in isolated islets. J Biol Chem 251: 1731-1737

20. Giroix M-H, Sener A, Pipeleers DG, Malaisse WJ (1984) Hexose metabolism in pancreatic islets: inhibition of hexokinase. Biochem J 223: 447-453

21. Salas M, Vinuela E, Sols A (1965) Spontaneous and enzymatically catalyzed anomerization of glucose 6-phosphate and anomeric specificity of related enzymes. J Biol Chem 240: 561-568

22. Bailey JM, Fishman PH, Pentchev PG (1968) Studies on mutarotases. II. Investigations of possible rate-limiting anomerizations in glucose metabolism. J Biol Chem 243: 4827-4831

23. Wurster B, Hess B (1973) The reaction of hexokinase with equilibrated D-glucose. Eur J Biochem 36: 68-71

24. Malaisse WJ, Deleers M, Malaisse-Lagae F, Sener A (1983) Anomeric specificity of hexose metabolism in pancreatic islets. Excerpta Medica ICS 600:345-351

25. Idahl L-Å, Sehlin J, Täljedal I-B (1975) Metabolic and insulin-releasing activities of D-glucose anomers. Nature 254: 75-77
26. Malaisse WJ, Giroix M-H, Dufrane SP, Malaisse-Lagae F, Sener A (1985) Anomeric specificity of glycolysis in a non glucokinasecontaining cell. Biochem Int 10: 233-240

27. Malaisse WJ, Leclercq-Meyer V, Sener A (1985) Glucokinase is not responsible for the anomeric specificity of glucose metabolism in pancreatic islets. Diabetes 34 (Suppl 1): $45 \mathrm{~A}$

28. Ashcroft SJH, Randle PJ (1970) Enzymes of glucose metabolism in normal mouse pancreatic islets. Biochem $J$ 119: 5-15

29. Trus MD, Zawalich WS, Burch PT, Berner DK, Weill VA, Matschinsky FM (1981) Regulation of glucose metabolism in pancreatic islets. Diabetes 30:911-922

30. Katz J, Wood $\mathrm{HG}$ (1963) The use of $\mathrm{C}^{14} \mathrm{O}_{2}$ yields from glucose-1 and $-6-\mathrm{C}^{14}$ for the evaluation of the pathways of glucose metabolism. J Biol Chem 238: 517-523

31. Giroix M-H, Dufrane SP, Malaisse-Lagae F, Sener A, Malaisse WJ (1984) Fasting-induced impairment of glucose-1,6-bisphosphate synthesis in pancreatic islets. Biochem Biophys Res Commun 119: 543-548

32. Matschinsky FM, Meglasson MD, Burch PT, Berner DK, Najafi H, Vogin AP, Garfinkel D, Garfinkel L (1983) Glucokinase (ATP:D-glucose 6-phosphotransferase, EC 2.7.1.2), the glucose sensor of pancreatic islet $\beta$-cells. Excerpta Medica ICS 600: 337-344

33. Malaisse WJ, Malaisse-Lagae F, Sener A (1982) The glycolytic cascade in pancreatic islets. Diabetologia 23:1-5

34. Sener A, Van Schaftingen E, Van De Winkel M, Pipeleers DG, Malaisse-Lagae F, Malaisse WJ, Hers H-G (1984) Effects of glucose and glucagon upon the fructose 2,6-bisphosphate content of pancreatic islets and purified B-cells. A comparison with isolated hepatocytes. Biochem J 221: 759-764

35. Giroix M-H, Sener A, Dufrane SP, Malaisse-Lagae F, Malaisse WJ (1985) Glucose metabolism in insulin-producing tumoral cells. Arch Biochem Biophys 241 (in press)

36. Meglasson MD, Matschinsky FM (1984) Purification of the putative islet cell glucose sensor glucokinase from isolated pancreatic islets and insulinoma tissue. In: Larner J, Pohl SL (eds) Methods in diabetes research, vol 1. John Wiley, New York, pp 213-226

37. Halban PA, Praz GA, Wollheim CB (1983) Abnormal glucose metabolism accompanies failure of glucose to stimulate insulin release from a rat pancreatic cell line (RINm5F). Biochem J 212: 439-443

38. Sener A, Levy J, Malaisse WJ (1976) The stimulus-secretion coupling of glucose-induced insulin release. XXIII. Does glycolysis control calcium transport in the B-cell? Biochem J 156: 521-525

Professor W.J.Malaisse

Laboratory of Experimental Medicine

Brussels Free University

115, Boulevard de Waterloo

B-1000 Brussels, Belgium 